\title{
Images of Muslims and Islam in Swedish Christian and Secular News Discourse
}

\begin{abstract}
Dr. Kristian Steiner
Senior lecturer, Peace and Conflict Studies, Malmö University, Sweden.

Kristian.Steiner@mah.se

Abstract

This is a descriptive comparative quantitative content analysis of the construction of Islam and Muslims in 2006-2007 in four Swedish publicationsthe liberal newspaper Dagens Nyheter representing mainstream media, the Evangelical newspaper Dagen, the fundamentalist newspaper Världen idag representing the Christian right, and the journal SD-Kuriren, the official organ of the Sweden Democrats, a neo-nationalist party. The aim is to see where a chasm between those media which accept the presence of Muslims and Islam in Sweden, and those which do not, occurs. The results put the liberal Dagens Nyheter and the Evangelical Dagen on one side of the divide and the fundamentalist Världen idag and the neo-nationalist SD-Kuriren on the other. Världen idag and SD-Kuriren tend to describe Muslims and Islam as threatening, and 'our' elite as retreating. In these two media Muslims are consistently described as aggressive and the cause of social and political problems. Lastly, in both media, Muslims are related to negative behavior; good Muslim behavior is constantly disregarded, while bad behavior is assumed to reflect their true character. Världen idag also claims that Islam is incompatible with democracy. Liberal Dagens Nyheter and Evangelical Dagen avoid describing Muslims and Islam as a threat and more often seek constructive solutions to different problems. Dagens Nyheter moreover describes conflicts between Muslim and Christian actors in political, not religious, terms. Dagen also sees Muslims and Christians alike as victims of the forces of secularization.
\end{abstract}

\section{Introduction}

The presence of a Muslim minority in Sweden is recent. Most Swedes have accepted this demographic and societal change, and so have most media and most political parties; the Sweden Democrats being the most important exception. However Sweden is still divided, and there is a chasm between those accepting this change and those who do not.

This is a comparative quantitative content analysis on Swedish media discourse on Muslims and Islam from 2006-2007 in two Christian and two secular publications. The overarching aim is to reveal where an important discursive chasm appears in the Swedish media landscape regarding the perception of Muslims and Islam. Four media have been selected strategically: Dagens Nyheter, ${ }^{1}$ the biggest Swedish morning paper, representing a liberal

\footnotetext{
1 Dagens Nyheter, founded in 1864, is the largest morning newspaper in Sweden with circulation in weekdays of 285000 and 330.000 on Sundays. It is regarded as an independent Liberal paper and important leader of public opinion in Sweden since World War II.
} 
and secular Swedish mainstream media. $S D$-Kuriren ${ }^{2}$ is a much smaller media product, a journal representing a neo-nationalist political party, the Sweden Democrats. Thus, it deviates from Dagens Nyheter in character; in regards to its purpose, size, and independence. Still, since SD-Kuriren is the leading neonationalist journal or newspaper on the Swedish market it has been selected for analysis.

The two remaining newspapers are conservative Christian and comparatively small: Dagen ${ }^{3}$ is conservative, Evangelical, and sometimes called an ecumenical, paper. Världen idag 4 is formally independent, but has close ties to Livets ord, in Uppsala (Eng. Word of Life), a charismatic fundamentalist church.

This is not the first study analyzing Western elite discourse on Muslims and Islam. Such research has been an important academic field ever since Edward Said's book Orientalism earned repute in the 1980s. According to Said and most scholars within the field, the dominant discourse on Muslims and Islam is negative. Muslims and Arabs have become the predominant 'other', and everything that 'we' are not (Shaheen 1985: 162). 'They' are supposedly irrational (Said 1978: 40, 287, 317), violent and inclined to terror (Beeman 2005: 140-8). Since 'they' have no proper conscience (Massad 2007: 44) 'they' only understand force (Massad 2007: 45) or sometimes shame and humiliation (Said 1978: 4-5). Likewise 'they' are represented as static, stagnant, misogynic, superstitious (Massad 2007: 13), and despotic (Brasted 1997: 7). Some images change though. Until the end of the nineteenth century, Arabs were described as decadent, in moral decline, degenerate, fallen, and sexually licentious (Massad 2007: 8). Nineteenth-century Orientalists had a "fascination with the sexual desires and lives of Arabs" (Massad 2007: 47). Interestingly, today it is in fact the Arabs' alleged repression of sexual freedoms which the West assaults (Massad 2007: 37). However, over the years 'they' remained 'our' inferior anti-thesis.

According to Said, this discourse became more diffused, and "has seemed more persuasive and influential, in the West than any other 'coverage' or interpretation" (Said 1978: 169) since it was reproduced by a variety of discursive elites, such as the academy, the government, poets, novelists, philosophers, political theorists, economists (Said 1978: 2-3), and the media (Said 1978: 169). In recent years this discourse has also been reproduced in Eurabia literature, with Gisélle Littman as a frontal figure (Steiner 2010: 58-

\footnotetext{
2 SD-Kuriren is a periodical with four annual issues and was founded in 1991 as the official organ for the Sweden Democrats. It has a circulation of about 28,000 . Occasionally it is accessible on Internet.

3 The leader of the Pentecostal movement founded Dagen in 1945. Currently the paper has 18,000 subscribers, Norwegian owners and is regarded as Evangelical or ecumenical.

${ }^{4}$ Världen idag was founded in 2001 and has today about 6.600 subscribers. The paper is a part of the faith movement and the Swedish Christian right.
} 
90) and in Evangelical, foremost Christian Zionist, literature, primarily in the United States, but also in Europe (Steiner 2010: 91-135; Steiner 2013).

Studies confirm that media also contributes to Orientalist discourse (Nohrstedt and Camauër 2006: 17; Abrahamian 2003). Arabs and Muslims are represented as violent and threatening (Manning 2006: 131). Muslims also supposedly threaten Western mainstream values and are accused of causing lasting tensions between ethno-religious groups in the UK (Poole 2006: 1012).

This image is usually not fashioned through explicit statements. More often space is given to negative reports, and little weight is attributed to nonWestern sources. Furthermore, the way certain news stories are labelled reveals the interpretative logic governing media. A murder within a Muslim family is by routine labeled as honor killing, thereby giving culture and religion a prominent role (Strand Runsten 2006: 200-1, 206). Individual crimes, as with killing, are described as something typical for the group and contribute to stereotypes (Strand Runsten 2006: 209).

Two main circumstances make this research relevant: firstly a possible alliance between neo-nationalist movements and conservative Christianity, and secondly presumed consequences of Islamaphobic media discourse.

The last 30 years, a new radical political right has emerged in Europe. The radical right is nationalist and populist, and suspicious towards Islam and Muslims (Mudde 1999:182, 185). The growth of the European radical Right accelerated in the 1980s (Mudde, 1999: 182). Several new parties were founded, or created out of splits in established ones. In a few cases, entire established parties turned in a populist, right-wing direction (Mudde, 2011: 7). The importance of these parties has grown, although their growth has slowed down, and they now have a voting share of around 10\% in 12 member states, (Mudde, 2011: 9).

For many years, this new radical right only had minimal success in Sweden. The success of New Democracy in the early 1990s was based on two charismatic leaders. When they stepped down, the party was not re-elected to the parliament (Rydgren, 2005: 8, 75). The Sweden Democrats was founded as early as in 1988 and was at that time perceived as an almost neo-Nazi party with close ties to the movement Maintain Sweden Swedish (Rydgren, 2005: 118). The party was marginalized. About 10 years ago the party was taken over by a set of young leaders who wanted to create a more acceptable rightwing party that could attract 'welfare nostalgic' voters in Sweden (Hellström, 2010: 102-03). For years this party had little success. In 2010 however, the Sweden Democrats gained seats in the national parliament and its electoral support is supposedly growing.

In Sweden, the growth and success of right-wing Christian movements is limited, with one exception; Livets ord in Uppsala. Still, the Christian right has not become a significant political force. Yet, I find it interesting studying an 
Islam and Muslim related discourse in these four media, in order to establish to what extent Christian conservative media adheres to a neo-nationalist or a liberal discourse. If Dagen, conservative and Evangelical, and Världen idag, fundamentalist charismatic, demonstrate a discursive consensus with $S D$-Kuriren with neo-Nazi roots, this might foreshadow an alliance between rightextremism and neo-conservative Christianity, especially since the Swedish Christian Democratic party is losing electoral support. It has been discussed whether the Sweden Democrats would seize the role the Christian Democrats once had. Thus, a discursive consensus regarding Islam and Muslims might indicate that the Sweden Democrats might have an opportunity to gain ground among conservative Christians.

The second reason for conducting this research is consequentialistic. It is well established that the ability to control media language is a power position (van Dijk, 1995: 19), and if such language becomes hostile, it is even considered as violence (Galtung, 1990: 291). Lastly, media language has a particular impact in areas where its audience has limited first-hand knowledge (Poole and Richardson, 2006: 1), like the readership of Christian papers regarding Islam, and if the discourse becomes hegemonic. According to Edward Said, an anti-Muslim and anti-Arab discourse has not only become mainstream (Said, 1997: xix, 25), it has become "the canonical, orthodox coverage of Islam ... and has been more diffused, has seemed more persuasive and influential, in the West than any other 'coverage' or interpretation" (Said, 1997: 169). He even claims that what can be said about Muslims cannot be said about any other group; it is the last acceptable form of denigration (Said, 1997: xii, xvi). In any case, since there seem to be some acceptance in the public sphere for antiMuslim sentiments, Christian media attitudes might be important for its readership.

On a general level, academic literature suggests that violent discourse, such as Islamophobia, has three effects: First of all it affects our ethics, restructures value hierarchies (Kempf, 2010: 13), it "preaches, teaches, admonishes, eggs on, and dulls us into seeing exploitation and/or repression as normal and natural" (Galtung, 1990: 291). It "makes direct and structural violence look, even feel, right—or at least not wrong", it changes "the moral color of an act", and it makes oppression legitimate (Galtung, 1990: 291). Truths, ethical considerations and individual rights become subordinate (Kempf, 2010: 13). Injustice, even war becomes necessity and justified (Kempf, 2010: 15). Secondly, a hostile discourse tends to influence (Fairclough, 1993: 138; Winter Jørgensen and Phillips, 1999: 13), and even distort (Wetherell and Potter, 1992: 13) the way we understand and interpret social reality. It makes reality opaque (Galtung 1990: 291), and can blind us to existing oppression (Galtung, 1990: 295).

Interestingly enough, discourse does not only precede or pave the way for violent behavior or oppressing structures. On the contrary, and this is the third 
effect, there is a stronger correlation between discrimination and oppressive language than the other way around. Thus, oppressive language has a system justification function; it legitimates existing social arrangements (Jost and Banaji, 1994: 2). This means that "disadvantaged groups are stereotyped in ways that justify their social position" (Jones, 2002: 11), since people cannot endure political systems harming a person who seems like oneself, because it would arouse "feelings of repentance and pain" (Sternberg and Sternberg, 2008: 45).

\section{Method}

This is a descriptive comparative quantitative content analysis. Using such a method enables the study to see not only differences and similarities between the news products, but also to identify nuances in their respective language (Landmann, 2008: 4-5).

The years under scrutiny, 2006 and 2007, were selected since they were years of intense conflict between islamophobic groups in the West and Islamists. Furthermore the political effects of the Danish Mohammed caricatures were evident; resulting in demonstrations and economic boycotts against Denmark. In Sweden, the website of the Sweden Democrats was closed for a short time, since the party published the caricatures. And lastly, parliamentarian elections were held both in Sweden and in the Palestinian territories resulting in a more heated political climate.

Although a wide variety of news materials occur in papers and journals, only the most ideologically distinctive material will be selected, explicitly reflecting the values of the media under scrutiny, i.e. editorials. Of these, those have been selected mentioning Islam and Muslims; Muslim organizations such as Hamas, Muslim terms such as Sharia, and Muslim individuals or ethnic groups with a Muslim majority.

In the case of Dagens Nyheter I have selected only the primary editorials. ${ }^{5}$ In the period 2006-2007, Dagens Nyheter published 710 leaders (356 in 2006), of these 169 concerned Muslims and Islam (94 in 2006).

The previously mentioned selection criteria cannot be fully applied on $S D$-Kuriren. Instead the selection has been expanded, so that not only editorials are included but all articles written by any member of the Sweden Democratic party board. This decision is based on the number of editorials being extremely small in $S D$-Kuriren and could not make a sufficient material for analysis. Furthermore, the selected articles are so politically distinctive that a comparison with editorials seems relevant. In 2006 and 2007 eight issues of SDKuriren were published, and in these issues members of the party board wrote 84 articles. Out of these 84 political articles, 34 were selected, making $40 \%$ of all the political articles. Richard Jomshof was the most active writer.

${ }^{5}$ I.e. first editorials. Henceforth called editorials. 
Table 1. Selected editorials and political articles 2006-2007 (2006)

\begin{tabular}{|c|c|c|c|c|c|c|}
\hline $\begin{array}{l}\text { Dagens Nyheter, } \\
\text { editorials }\end{array}$ & $\begin{array}{l}\text { SD-kuriren, } \\
\text { political articles }\end{array}$ & & $\begin{array}{l}\text { Dagen, } \\
\text { editorials }\end{array}$ & & $\begin{array}{l}\text { Världen idag, } \\
\text { editorials }\end{array}$ & \\
\hline \multirow[t]{7}{*}{ Anonymous $^{6}$} & Richard Jomshof & $23(11)$ & Thomas Österberg & $31(11)$ & Mats Tunehag & $100(42)$ \\
\hline & Mattias Karlsson & $5(1)$ & Birger Thureson & $15(15)$ & Ruben Agnarsson & $13(7)$ \\
\hline & Björn Söder & $3(2)$ & Erika Cyrillus & $11(11)$ & Hans-Göran Björk & $6(6)$ \\
\hline & Jimmy Åkesson & $2(1)$ & Elisabeth Sandlund & $10(1)$ & Carin Stenström & $6(5)$ \\
\hline & Tony Wiklander & $1(1)$ & Håkan Arenius & $5(0)$ & Siewert Öholm & $1(0)$ \\
\hline & & & Daniel Grahn & $3(3)$ & No signature & $1(0)$ \\
\hline & & & Olof Djurfeldt & $1(0)$ & & \\
\hline$(24 \%)$ & $(40 \%)$ & & $(19 \%)$ & & $(21 \%)$ & \\
\hline \multicolumn{2}{|l|}{$169(94)$} & $34(16)$ & & $76(41$ & & $127(60)$ \\
\hline
\end{tabular}

Dagen published approximately 200 editorials yearly, one per issue. Out of these 76 editorials (41 in 2006) were selected. Världen idag published approximately 300 editorials yearly, two in each issue. Based on the aforementioned criteria, 127 editorials were selected from the 2006-07 issues (60 in 2006), which is approximately $21 \%$ of all editorials.

Lastly, in this study Robert M. Entman's framing analysis functions both as an analytical as well as an organizing tool of the study. According to Entman, framing

is to select some aspects of a perceived reality and make them more salient in a communicating text, in such a way as to promote a particular problem definition, causal interpretation, moral evaluation and/or treatment recommendation for the item described. Typically frames diagnose, evaluate and prescribe. (Entman, 1993: 52)

Analytically, the study has developed and refined a method based upon Entman's keywords diagnosing, evaluating and prescribing, and is likewise using the same keywords to organize the study into three sections. In some sections, I develop more specific attendant operational questions.

\section{The Diagnoses}

Editorials and ideological articles are usually spurred by political problems. Success stories are rarely an inspiration. That problems characterize these articles is not necessarily a consequence of anti-Muslim attitudes per se. Nevertheless, a problem arises when European Muslims do not possess tools to articulate alternative public images. Statements might go unchallenged and contribute to an anti-Muslim discourse.

\footnotetext{
6 Traditionally, editorials are anonymous and merely the voice of the newspaper, like in the case of Dagens Nyheter. The other publications publish the names of their writers.
} 
It is difficult to categorize editorials according to their diagnoses, sometimes there is more than one, and sometimes they are unclear. Still, the editorials are classified inductively, identifying the most pertinent diagnoses without predefined categories, the reason being that this makes the articles at this early stage appear open-ended and in their own right.

Table 2a. Diagnosis, the motive for editorials with a Muslim presence in Dagens Nyheter 2006-2007 (2006)

\begin{tabular}{|l|r|}
\hline Diagnosis & Number \\
\hline 1 National policies & \\
Swedish foreign and security policies & $85(47)$ \\
Swedish domestic policies & $14(7)$ \\
American Iraq policies & $25(14)$ \\
American foreign and security policies & $9(5)$ \\
American domestic policies & $10(5)$ \\
French foreign and security policies & $3(1)$ \\
French domestic policies & $1(0)$ \\
Russian foreign and security policies & $2(0)$ \\
Russian domestic policies & $3(2)$ \\
British domestic policies & $3(3)$ \\
Danish domestic policies & $3(1)$ \\
EU foreign and security policies & $1(0)$ \\
EU domestic policies & $3(3)$ \\
2 International conflicts & $8(6)$ \\
Balkan conflicts & $29(13)$ \\
Arab-Israeli conflicts & $6(0)$ \\
Darfur conflict & $13(8)$ \\
Iraqi conflict & $4(2)$ \\
Afghan conflict & $4(2)$ \\
3 Muslim threats & $2(1)$ \\
Iranian nuclear capability & $23(16)$ \\
Threats against Western democracy & $7(4)$ \\
Western defense of democracy and human rights & $11(8)$ \\
The collapse of Pakistan & $2(2)$ \\
Anti-Semitic threats & $1(0)$ \\
Threats against Swedish Muslims & $1(1)$ \\
Totally Non-Muslim threats & $1(1)$ \\
Nuclear arms proliferation and arms race & $9(5)$ \\
Climate change & $7(5)$ \\
5 Democracy & $2(0)$ \\
Democracy in Pakistan & $8(3)$ \\
Democracy in Palestine & $3(0)$ \\
Democracy in Turkey & $1(1)$ \\
Elections in Iraq and Palestine & $3(1)$ \\
\hline
\end{tabular}


In the case of Dagens Nyheter (table 2a), its most common diagnosis concerns national policies, domestic or foreign, of different states. Furthermore, Dagens Nyheter is mainly using a non-religious discourse. Religion is rarely described as the motivation for political actors. The same can be said about the other categories; whenever international conflicts, threats, and democracy are discussed the role of religion is downplayed. Likewise, violence and political problems are dressed in a political language, not a religious one. Muslim actors are portrayed as politicians with a political, not a religious, agenda. This also holds true in the case of future Iranian nuclear capability (Dagens Nyheter, 16 January, 2006).

In Dagen (table 2b), the dominant category concerns secularization of the Swedish society, particularly Swedish schools. In these cases Muslims and Christians sometimes share the same challenge (Österberg, 30 November 2006), occasionally Muslims are used by anti-Christian actors with the pursuit of secularizing schools (Österberg, 13 June 2006; Cyrillus Olsson, 22 August 2006). But Muslim actors are never described as the central actor causing secularization.

Table 2b. Diagnosis, the motive for editorials with a Muslim presence in Dagen 2006-2007 (2006)

\begin{tabular}{|l|r|}
\hline Diagnosis & Number \\
\hline Swedish policies & $27(18)$ \\
Secularization in Sweden & $18(14)$ \\
Attitudes towards Muslims in Sweden & $4(2)$ \\
Swedish immigration policies & $3(1)$ \\
Swedish defense policies & $2(1)$ \\
2 International conflicts and conditions & $30(15)$ \\
The relationship between Muslims and Christians or & $11(6)$ \\
the western world & $10(6)$ \\
The Israeli-Palestinian conflict & $5(2)$ \\
The Iraq conflict & $4(1)$ \\
Poverty and conflicts in the third world & $7(3)$ \\
3 Democracy & $5(2)$ \\
Threats against freedom of expression & $2(1)$ \\
Islam and democracy & $4(3)$ \\
4 Human rights & $2(2)$ \\
Possession and proliferation of nuclear arms & $2(1)$ \\
Death penalty & $8(2)$ \\
5 Remaining & $76(41)$ \\
Totally & \\
\hline
\end{tabular}


Another major category concerns the relationship between Muslims and Christians or the western world. In this category ${ }^{7}$ threats are present. However Islamism, not Islam, is defined as an inspiration for terrorism in Sweden (Thureson, 5 May 2006), and is said to be "advancing" (Thureson, 8 June 2006) or responsible for terrorism in Great Britain (Österberg, 11 August 2006; Sandlund, 5 July 2007).

A third theme concerns the Israeli-Palestinian conflict. In this period the war between Hezbollah and Israel in the summer 2006 was a central theme as well as the fact that Hamas won the Palestinian elections and the illness of Ariel Sharon. Problematic Arab actors are described as individuals, not as representatives of Arabs or Muslims in general. Still, Palestinian leaders are repeatedly described as causing the conflict; they fight each other (Cyrillus, 14 June 2006), Hamas refuse to recognize Israel (Österberg, 4 April 2007; Thureson 1 August 2006), with the pursuit of eradicating Israel (Thureson, 11 May 2006). On the other hand, the Palestinian population is described as longing for peace (Thureson, 11 May 2006).

In Världen idag (table 2c) by far the most reoccurring diagnose concerns different Muslim threats, one kind being physical threats posed against the West. Islam allegedly threatened Denmark during the hot-headed demonstrations against Jyllands-Posten, the Danish paper that published the Mohammed caricatures (Tunehag, 2 January 2006). Furthermore, the life of a reporter at the Norwegian Christian paper, Magazinet, was threatened, and Hans-Göran Björk speculates whether this reveals the true face of Islam (Björk, 13 January 2006). The fact that the Danish embassy in Damascus was set on fire (Stenström, 6 February 2006) and that the leaders in Iran launched a nuclear program (Tunehag, 10 March 2006) are seen as additional physical threats against the West.

Likewise, Muslims allegedly threaten Western immaterial core values, such as religious freedom, democracy, and freedom of speech and expression. The existence of radical Muslims in Europe is one such threat (Tunehag, 31 January 2007). In one editorial, The Islamic Republic of Sweden?, it is implied that British Muslims threaten democracy and support Sharia (Tunehag, 8 March 2006), and in another one, that 'we' all might be forced to follow Islam (Tunehag, 13 February 2006).

A second theme appearing in some editorials is the retreat of various Western elites from important Christian or democratic values, particularly when facing a Muslim threat. This retreat is described in a typically populist vein. It is supposedly caused by Muslim immigration and ignorant and naïve Western elites fearing Muslim immigrants. A clear case is the excuse Denmark's Prime Minister and the chief editor of Jyllands-Posten gave the Muslim

\footnotetext{
7 Threat is also present in articles concerning the Israeli-Palestinian conflict and in the ones concerning possession and proliferation of nuclear arms.
} 
world after publishing the Mohammed drawings. Allegedly, 'they' are now letting Islam rule a Scandinavian democracy (Björk, 3 February 2006). Not only is the political elite sounding the retreat, so also are "ignorant secularists" and "media” as well (Tunehag, 7 June 2006). 'They' allow a self-censorship to wildfire, limiting the freedom of speech and expression, especially in issues related to Islam and homosexuality (Tunehag, 8 November 2006).

Table 2c. Diagnosis, the motive for editorials with a

Muslim presence in Världen idag 2006-2007 (2006)

\begin{tabular}{|l|r|}
\hline Diagnosis & Number \\
\hline 1 Muslim threats, responses and consequences & $57(30)$ \\
Muslim threats & $35(17)$ \\
Muslim threats and Western/Swedish retreat & $17(10)$ \\
Muslim threats and Swedish foreign policy & $1(1)$ \\
Muslim threats and the behavior of the Swedish left & $1(1)$ \\
Muslim threats and democracy & $3(1)$ \\
2 Democracy and Islam & $22(7)$ \\
Islam's incompatibility to democracy & $17(7)$ \\
Islam, democracy and others & $2(0)$ \\
Islam's incompatibility to democracy and retreat & $1(0)$ \\
Children as subjects of Islamist propaganda & $2(0)$ \\
3 Swedish and Western policies and social change & $21(14)$ \\
Swedish foreign policies & $7(7)$ \\
Swedish and Western retreat & $3(2)$ \\
Media critique & $3(2)$ \\
The behavior of the Swedish left & $1(1)$ \\
Swedish foreign policy and mass media critique & $1(1)$ \\
Secularization & $3(1)$ \\
Hate crime & $3(0)$ \\
4 Remaining & $27(9)$ \\
Totally & $127(60)$ \\
\hline
\end{tabular}

A third diagnosis concerns the perceived incompatibility between Islam and democracy. Islam is described as genuinely undemocratic. Muslim societies are supposedly unable to adopt democratic values (Tunehag, 27 February 2006). Tunehag calls democratic Islam a "square circle": a contradiction in terms (Tunehag, 30 January 2006).

The analysis of $S D$-Kuriren (table $2 \mathrm{~d}$ ) establishes major rhetorical similarities with Världen idag, but also some differences. A shared feature is the alleged Muslim threat as a reoccurring theme. Threat is the dominating or one of two dominating problems in more than $60 \%$ of the selected political articles. This is a larger proportion than in Världen idag.

Unlike Världen idag, $S D$-Kuriren never claims that Islam as such is incompatible to democracy. However, just like Världen idag, SD-Kuriren dwells on the idea that Muslims in Europe constitute a threat to democracy. In 2006, Richard 
Jomshof describes the reactions against the publications of the Mohammed images as a threat and an assault on the free and democratic Denmark, enabled by Danish Muslims, labeled "fifth columnists" (Jomshof, 67b, 2006). This expression reoccurs in an article by Björn Söder, who claims that Muslims conduct "fifth column activities" (Söder, 67, 2006). Söder also refers to Pia Kjærsgaard, claiming that "there are strong Muslim forces that wish to curtail our democratic rights" (Söder, 69, 2006).

Furthermore, the writers return to the idea that the Muslim threat is permanent and growing since 'they' are here, their number is growing and since 'they' assumedly are getting more radical. The Muslim group assumedly "grow increasingly fast" through "mass immigration and high nativity" (Jomshof, 69a, 2006), and "will cause very big problems in the future" (Jomshof, 69a, 2006) as they will demand "antidemocratic Sharia laws", Muslim autonomy and segregation (Jomshof, 69d, 2006).

Table 2d. Diagnosis, the motive for editorials with a Muslim presence in SD-kuriren 2006-2007 (2006)

\begin{tabular}{|l|r|}
\hline Diagnosis & Number \\
\hline 1 Muslim threats & $21(12)$ \\
Muslim threats & $11(6)$ \\
Muslim threats and Western/Swedish retreat & $7(4)$ \\
Muslim threats and democracy & $1(1)$ \\
Muslim threats and remaining & $2(1)$ \\
2 Swedish policies & $9(2)$ \\
The treatment of SD by the Swedish political & $5(0)$ \\
establishment & $2(2)$ \\
Western/Swedish retreat & $2(0)$ \\
Defining Swedishness & $4(2)$ \\
3 Remaining & $34(16)$ \\
Totally & \\
\hline
\end{tabular}

These problems are understood as permanent since cultures, in Richard Jomshof's mindset, do not converge. The system with independent schools, furthermore, will contribute to the permanency of the problem giving Muslims the opportunity to reproduce its culture and religion independently (Jomshof, 74b, 2007). Being an ardent supporter of Christian independent schools, Världen idag refrain from this critique.

Just as in Världen idag, also in SD-Kuriren Muslims are portrayed as violent and irrational. The threat they constitute is not merely a threat to democratic ideas, but they also supposedly constitute a real physical threat and a threat to law and order. In 2005 violent riots took place in some of the suburbs of Paris and in 2007 SD-Kuriren reported on riots in Netherlands (Jomshof, 72b, 2007). Jomshof and Söder depict how Muslim youth in France make up the basis of the problem and cause a situation described as the "brink 
of civil war" (Jomshof and Söder, 67, 2006). In the same article it is also said that an "Arab mob", without any rational reasons, assaulted passengers on a train in Nice. The authors also emphasize that this is not an isolated French threat, but also a Swedish and European one.

$S D$-Kuriren stresses that crime and sexual violence is yet another kind of Muslim threat and an outcome of Islam. In the mindset of $S D$-Kuriren, crime is not merely a social or legal issue, if the perpetrator is Muslim. Crime is understood as a part of a global war between the Muslim world and the West (Karlsson, 74, 2007; Karlsson, 68, 2006) and is seen as an outcome of Islamic attitudes, since "Muslim violence against infidels to a large extent is based upon attitudes towards women, men, sex, and violence thriving in Muslim societies" (Jomshof, 74a, 2007).

Another reoccurring theme in $S D$-Kuriren is the retreat of Western elites. Herein lies $S D$-Kuriren's populist dimension, shared by Världen idag; voicing a mistrust of national elites and depicting them as ignorant and blind to massive threats posed by Islamic presence in the West. Moreover, a wide group of elites is criticized. One is artists. $S D$-Kuriren claims that the refusal of children's book illustrators' to make drawings of Mohammed was a retreat and the origin of the crisis (Jomshof, 67b, 2006). This was understood by SD-Kuriren as a symptom of that Denmark voluntarily "subject" itself to "Islamic censorship". Likewise, Jomshof regards the refusal to accept Lars Vilks' participation in an exhibition in Karlstad in the summer 2007 (Jomshof, 73, 2007) as well as the closure of $S D$-Kuriren's website in 2006, probably under pressure from the foreign minister (Jomshof, 67a, 2006; Jomshof, 69b, 2006; Jomshof, 74c, 2007) as yet other symptoms of retreat.

Just as Världen idag, SD-Kuriren sometimes uses historical analogies, comparing contemporary actors to the ones in the 1930s and -40s. Scandinavian media is described as appeasers (Wiklander, 67, 2006), and similarly, Dutch media allegedly "suppress and belittle" the riots outside Utrecht (Jomshof, 72b, 2007). Furthermore, Swedish and British politicians are described as "appeasers" against those Muslims who want to impose Sharia (Jomshof, 68, 2006).

\section{Evaluation of Muslims' Moral Character}

The second phase in Entman's framing method concerns the moral evaluation of actors in a discourse. This extensive section is divided into subsections based on more specific attendant operational themes. The first section is analyzing explicit claims regarding Muslims' moral character, and the second implicit ones.

\subsection{Explicit Descriptions of Muslims}

In this analysis regarding explicit claims about Muslims and Islam, the roles Muslims are given in the articles will be analyzed; thereafter attention will be 
given to the usage of labels and complements. Exploring the role Muslims play in relation to diagnoses in editorials, the extent Muslims are regarded as problem-makers, as possessing a passive, neutral, unclear role or described as problem-solvers, will be studied.

News media differ greatly with respect to assignment of responsibilities. As table 3 indicates, the four media can be divided into those where Muslim actors in general have a neutral, passive or unclear role, and those where Muslim actors in general have the role as rejected problem-makers. The reason for this difference is, in addition to ideological differences, the fact that Muslims are not in main focus in many of the editorials in Dagen, such as in articles on secularization. In the case of Dagens Nyheter, several articles focus on political structures and contexts, explaining a political problem, and tend to downplay the role of actors, including Muslim ones.

Table 3. The roles of the Muslim actors in relation to the problems and diagnoses of the editorials (percent and number)

\begin{tabular}{l|c|c|c|c|} 
& $\begin{array}{c}\text { Muslim actor in } \\
\text { Dagens Nyheter } \\
2006-07 \\
\mathrm{~N}=167\end{array}$ & $\begin{array}{c}\text { Muslim actor in } \\
\text { Dagen } \\
2006-07 \\
\mathrm{~N}=76\end{array}$ & $\begin{array}{c}\text { Muslim actor in } \\
\text { Världen idag } \\
2006-07 \\
\mathrm{~N}=127\end{array}$ & $\begin{array}{c}\text { Muslim actor in } \\
\text { SD-Kuriren } \\
2006-07 \\
\mathrm{~N}=34\end{array}$ \\
\cline { 2 - 5 } $\begin{array}{l}\text { Rejected } \\
\text { problem-maker }\end{array}$ & $40(67)$ & $36(27)$ & $81(103)$ & $77(30)$ \\
\cline { 2 - 5 } $\begin{array}{l}\text { Passive, neutral } \\
\text { or unclear role }\end{array}$ & $77(128)$ & $70(53)$ & $38(48)$ & $15(6)$ \\
\cline { 2 - 5 } $\begin{array}{l}\text { Accepted } \\
\text { problem-solver }\end{array}$ & $7(11)$ & $14(11)$ & $9(11)$ & $8(3)$ \\
\cline { 2 - 5 }
\end{tabular}

In Världen idag, as well as in $S D$-Kuriren, Muslims are repeatedly described as problem-makers. However, there is one difference; in the case of Världen idag Muslims relatively often also have a passive, neutral, or unclear role. The reason is that several articles in Världen idag, unlike SD-Kuriren, depict different Muslim actors in different roles, i.e. more than one kind of Muslim actor is present.

The analysis of the usage regarding labels denoting Muslims, deals with the denotative precision and connotative value of labels (Ottosen, 1995:100). Combining negative connotations with vague denotations is an effective strategy to incite prejudice. ${ }^{8}$

\footnotetext{
8 The concept of connotation is complicated. There is no impartial wordlist naming all dysphemisms and euphemisms. What is a disparaging label depends on the context (Ejvegård 2005: 16). If there is reason to believe that a writer has the intention to speak in a derogatory manner, to vulgarize, or to describe someone as offensive, then the term is disparaging, particularly if we believe that the audience understands the terms in question in the same way.
} 
In this case no major differences between the four media appear. All of them seem to consciously avoid dysphemisms, and other labels with negative connotation (table 4a-d). However, that does not mean that the usage of labels is identical, as a few qualitative examples might illustrate.

As in the other media, neutral or vague labels dominate in Dagens Nyheter. And furthermore, $46 \%$ of the labels denote ambiguously. Furthermore, the fact that the editorials have a secular language, also have an im plication on the usage of labels depicting Muslims; they are usually secular. Also in the ones with negative connotation, about 17\%, Dagens Nyheter regularly avoids emphasizing their Muslim character. Regimes, governments, terrorists, presidents are rarely referred to as 'Muslim' regimes or a 'Muslim' government and so on. Also when "fanatics" are being discussed, they are not referred to as 'Muslim', and "extremists" furthermore, are referred to as "extremists of both sides" (Dagens Nyheter, 7 February 2006).

Table 4a. Labels denoting Muslim actors in Dagens Nyheter 2006-2007 (percent and number) N=399

\begin{tabular}{|c|c|c|c|}
\hline & & Denota & \\
\hline & & Unequivocal & Ambiguous \\
\hline & $\begin{array}{r}\text { Unequivocally } \\
\text { positive }\end{array}$ & $3(10)$ & $1(3)$ \\
\hline Connotation & $\begin{array}{r}\text { Neutral or } \\
\text { vague }\end{array}$ & 44 (175) & $36(142)$ \\
\hline & $\begin{array}{r}\text { Unequivocally } \\
\text { negative }\end{array}$ & $8(33)$ & $9(36)$ \\
\hline
\end{tabular}

The usage of labels in Dagen resembles to a large extent the one in Dagens Nyheter, particularly regarding the distribution of the labels in the different categories. But since Dagen is Evangelical, it has a tendency to have a more religious language, to Islamize labels designating Muslim actors, turning militant actors into "militant Muslims" (Thureson 1 February 2006) and regimes into "theocratic Arab countries" (Cyrillus 15 November 2006). This might be a bit surprising since Dagen tends to have a more benign outlook on Islam and Muslims in other respects. 
Table 4b. Labels denoting Muslim actors in Dagen 2006-2007 (percent and number) $\mathrm{N}=222$

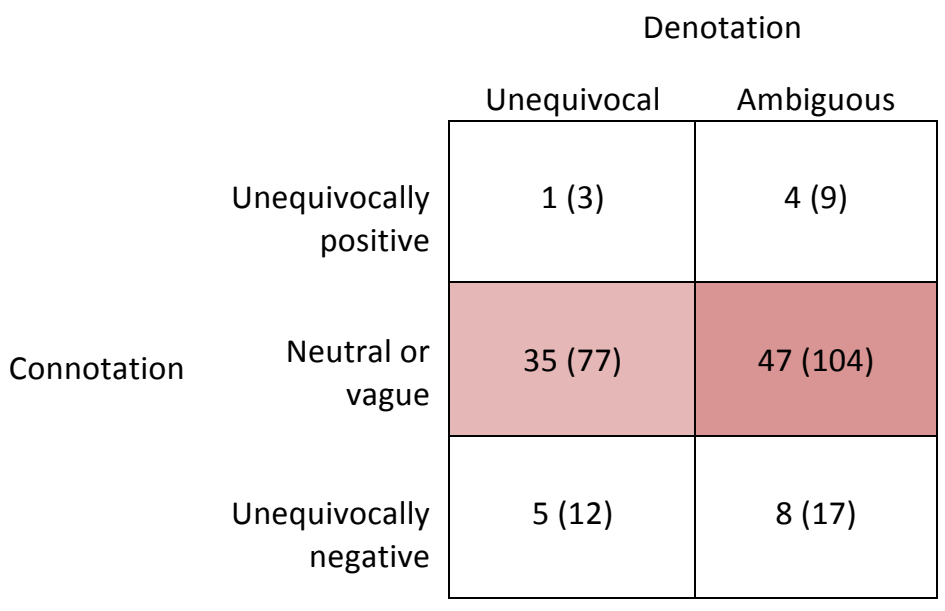

Världen idag's 127 editorials have 608 labels of Muslims, significantly more than Dagens Nyheter publishing significantly more editorials. Of these labels, $13 \%$ fall into the category of labels with an unequivocally negative connotation (table 4c), the same proportion as Dagen. And labels with vague or neutral connotation dominate, as in other media. Labels with a positive connotation are exceptionally rare.

Of the labels denoting Muslims, 54\% denote ambiguously, 46\% include terms combining an ambiguous denotation and a neutral or vague connotation such as "Muslims", "Islam", "Muslims in our countries" or "Muslim groups".

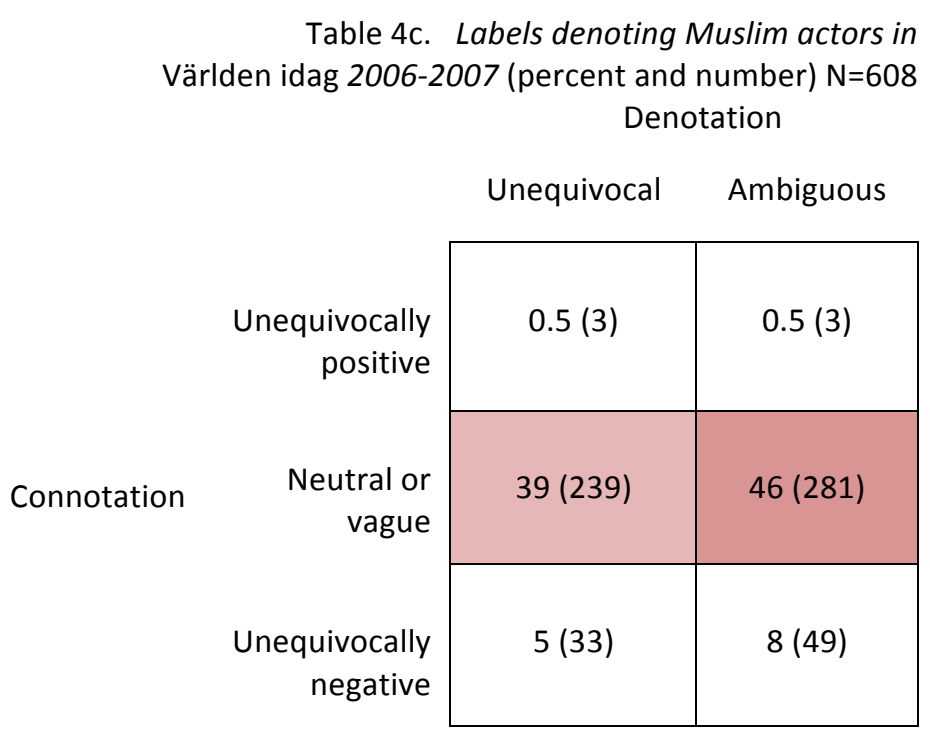

Of course, the most problematic category is the one combining derogatory connotation with unspecific denotations, and here we find "Islamic extremists" (Björk, 13 January 2006), "this religion of violence" (Stenström, 6 February 2006), "dangerous religion", (Stenström, 6 February 2006), "the wolfs" (Björk, 8 May 2006), "the terrorists" (Tunehag, September 6 2006), and "these bawlers" (Tunehag, 18 September 2006). 
$S D$-Kuriren's usage of labels is consistent with the other media (table 4d). In 34 articles, 184 labels denoting Muslim actors have been found, 12\% are classified as negative. This means that just as other media, $S D$-Kuriren does not allow labels with negative connotation to dominate. Likewise, vague or neutral labels dominate the editorials in SD-Kuriren.

In all of the publications, except Dagens Nyheter, there is a tendency to ambiguity. In SD-Kuriren 54\% of the labels denoting Muslims are ambiguous, possibly indicating that the writers generalize to same extent, but avoid using negatively charged labels. The dominant category is labels combining an ambiguous denotation with a neutral or vague connotation, such as "Muslims" (Jomshof, 67a, 2006; Jomshof, 72b, 2007; Jomshof, 74b, 2007), "increasingly more Muslims" (Jomshof, 67a, 2006; Jomshof, 69a), "strong Muslim forces" (Söder, 67, 2006), and "Islam" (Söder, 67, 2006; Söder, 69, 2006; Jomshof, 72a, 2007).

The most ethically problematic labels, those combining a denotative ambiguity with negative connotation, represents $8 \%$ of the total. In the case of Världen idag many of these labels were clear dysphemisms. In SD-Kuriren all the dysphemisms are borderline cases, less malicious forms of dysphemisms,

Table 4d. Labels denoting Muslim actors in SD-kuriren 2006-2007 (percent and number) N=184 Denotation

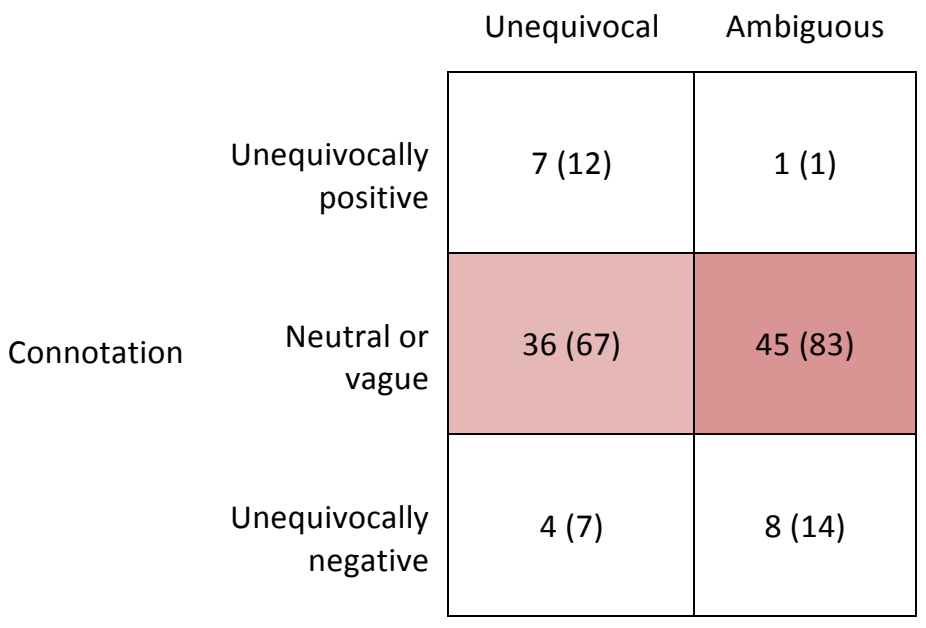

such as "a too big Muslim population in Sweden" (Jomshof, 69a, 2006; Jomshof, 74b, 2007), "Muslim fundamentalists" (Jomshof, 74b, 2007) and the "alleged moderate Muslims" (Karlsson, 72b, 2007).

All in all, this implies that the four media in many ways coincide in the usage of labels as an instrument to describe Muslims although ambiguous are considerably more vulgar in the case of Världen idag.

In the scrutiny of explicit descriptions of Muslims, we have now come to complements, i.e. the clause element describing what Muslims are, what they are not and so on. Such statements are divided into six categories, into those 
making clear positive statements, neutral or vague statements, and complements making unequivocally negative statements. Moreover, the statements are divided along another dimension concerning the denotative clarity of the subjects in the clauses. Of course, the most malicious clause combines an ambiguous actor with a negative complement.

In this case, the four media falls into two categories; those where neutral or vague complements dominate (Dagens Nyheter and Dagen) and those where negative ones dominate (Världen idag and SD-Kuriren). Furthermore, Dagens Nyheter's complements express secular, and political conditions, also when terrorism is described. For instance "the terrorist is a dangerous and unpredictable enemy" (Dagens Nyheter, 11 August 2006). Furthermore, as an effect of the secular discourse in this newspaper, the subjects in the sentences, although defined as Muslim, are of a secular and very neutral character, like countries, politicians and organizations, and so on.

Table 5a. The Use of Complements describing Muslims in Dagens Nyheter 2006-07 (percent and number) $\mathrm{N}=101$

Denotation of subject label

\begin{tabular}{|c|c|c|c|}
\hline \multirow{2}{*}{\multicolumn{2}{|c|}{$\begin{array}{r}\text { Unequivocally } \\
\text { positive }\end{array}$}} & Unequivocal & Ambiguous \\
\hline & & $8(8)$ & $5(5)$ \\
\hline \multirow[t]{2}{*}{ Complements } & $\begin{array}{r}\text { Neutral or } \\
\text { vague }\end{array}$ & $21(21)$ & $28(28)$ \\
\hline & $\begin{array}{r}\text { Unequivocally } \\
\text { negative }\end{array}$ & $18(18)$ & $21(21)$ \\
\hline
\end{tabular}

Dagen resembles Dagens Nyheter in its usage of Muslims complements; neutral and vague ones dominate. And furthermore, although Dagen has more of a religious language, it does not affect its usage of complements. Both its subjects and the complements are dominated by secular terms. The religious subjects that do exist are predominantly positive or in some cases neutral, like "moderate Muslims are an overwhelming majority in our country" (Thureson, 17 May 2006). And lastly, sentences with negative complements are usually describing corrupt politicians and organizations. 
Table 5b. The Use of Complements describing Muslims in Dagen 2006-07 (percent and number) $\mathrm{N}=34$

\begin{tabular}{|c|c|c|c|}
\hline & & Denotation & bject label \\
\hline & & Unequivocal & Ambiguous \\
\hline & $\begin{array}{r}\text { Unequivocally } \\
\text { positive }\end{array}$ & $12(4)$ & $3(1)$ \\
\hline Complements & $\begin{array}{r}\text { Neutral or } \\
\text { vague }\end{array}$ & $24(8)$ & $35(12)$ \\
\hline & $\begin{array}{r}\text { Unequivocally } \\
\text { negative }\end{array}$ & $18(6)$ & $9(3)$ \\
\hline
\end{tabular}

Världen idag deviates from Dagen and Dagens Nyheter. First of all, in Världen idag complements are more frequent, and there is a clear tendency towards negative statements (Table 5c). In $62 \%$ of the clauses, its writers make unequivocally negative statements. Merely $6 \%$ of the complements are positive. However, a qualitative scrutiny of these six cases reveals that not even these statements are affirmative. The confirmatory complements are in some cases contrasted with a 'but' devaluating the impression. For instance "Muslims are part of Swedish society, but we cannot accept measures that will create 'the Islamic republic of Sweden'” (Tunehag, 8 March 2006).

Table 5c. The Use of Complements describing Muslims in Världen idag 2006-07 (percent and number) N=104

\begin{tabular}{|c|c|c|c|}
\hline \multirow{3}{*}{\multicolumn{2}{|c|}{$\begin{array}{r}\text { Unequivocally } \\
\text { positive }\end{array}$}} & \multicolumn{2}{|c|}{ Denotation of subject label } \\
\hline & & Unequivocal & Ambiguous \\
\hline & & $1(1)$ & $5(5)$ \\
\hline \multirow[t]{2}{*}{ Complements } & $\begin{array}{r}\text { Neutral or } \\
\text { vague }\end{array}$ & $19(20)$ & $13(14)$ \\
\hline & $\begin{array}{r}\text { Unequivocally } \\
\text { negative }\end{array}$ & $33(34)$ & $29(30)$ \\
\hline
\end{tabular}

The 34 cases with vague or neutral complements are very simple and concrete statements. The most malicious sentences, i.e., those 30 cases combining depreciative complements and ambiguously labeled actors, are sometimes truly hostile, such as "Islam is a dangerous religion, a direct threat to the free world" (Stenström, 6 February 2006).

In SD-Kuriren, 51 clauses with a complement are found (table $5 \mathrm{~d}$ ). Of these complements, 30 (59\%) are defined as negative. In $S D$-Kuriren one single clause with a positive complement is to be found, and this one is no irony. Here 
the writer and debater Dilsa Demirbag-Sten is described in genuinely positive manner, "talented", and is portrayed as a role model for other immigrants (Wiklander, 67, 2006). The number of neutral complements is comparatively high, $40 \%$.

The most malicious category, where unequivocally negative complements are combined with ambiguous subjects, is prevalent in $S D$-Kuriren. More or less half of the complements are negative with a wide reference. In an article from 2006, Richard Jomshof claims that Muslims "have become more radical", "were willing to resort to physical violence" and "such actions show clearly how dangerous Islam as a religion is" (Jomshof, 69a, 2006).

Table 5d. The Use of Complements in descriptions of Muslims in SD-Kuriren 2006-2007 (percent and number) $\mathrm{N}=51$

\begin{tabular}{|c|c|c|c|}
\hline & & Denotation & ubject label \\
\hline & & Unequivocal & Ambiguous \\
\hline & Unequivocally & $2(1)$ & $0(0)$ \\
\hline Complements & Neutral or & $22(11)$ & 18 (9) \\
\hline & $\begin{array}{r}\text { Unequivocally } \\
\text { negative }\end{array}$ & $12(6)$ & 47 (24) \\
\hline
\end{tabular}

\subsection{Implicit Descriptions of Muslims}

Presumably, debaters and writers avoid making explicit claims and assaults. Therefore, in this section, another linguistic layer will be considered, studying implicit moral assessment of Muslims. Here allegedly Muslim behavior will be analyzed. However, analyzing verbs alone is not sufficient since verbs alone do not reveal the moral character of behavior alone. In order to reveal this, the inclusion of a direct object and in some cases the adverbial depicting how something is done is required. All in all, this section examines the moral standard of behavior attributed to Muslim actors by analyzing verbs, direct objects and adverbials.

Also in this case we can see a striking resemblance between $S D$-Kuriren and Världen idag (Table 6c-d). These two media repeatedly relate morally questionable behavior to ambiguous Muslim actors, making Muslims in general responsible. This linguistic technique is the one where Muslims most consistently are depicted in negative terms.

Dagens Nyheter connects Muslim actors to negative behavior in $42 \%$ of the cases, but more often with a well-defined actor, making individual leaders or organizations responsible, not Muslims in general. Still in 15\% of the cases, ambiguous actors are connected to negative behavior, particularly in the 
heated Mohammed caricature debate, in statements like "Muslims all over the world demand respect from Denmark" (Dagens Nyheter, 11 January 2006).

Table 6a. The behavior of Muslim actors in Dagens Nyheter 2006-07 N=365 (percent and number)

\begin{tabular}{|c|c|c|c|}
\hline & & Denotation & ubject label \\
\hline & & Unequivocal & Ambiguous \\
\hline & $\begin{array}{r}\text { Unequivocally } \\
\text { positive }\end{array}$ & $7(26)$ & $3(12)$ \\
\hline $\begin{array}{l}\text { The moral } \\
\text { character of the }\end{array}$ & Neutral or vague & 27 (100) & $20(73)$ \\
\hline & $\begin{array}{r}\text { Unequivocally } \\
\text { negative }\end{array}$ & 27 (99) & $15(55)$ \\
\hline
\end{tabular}

The editorials in Dagen are slightly different in one important aspect. Although Dagen too associates Muslim actors with morally dubious behavior, this is done less frequently. In 13\% of the cases furthermore, wide categories of Muslims are made responsible for negative behavior, which is in comparison to other media, relatively few cases. Moreover, negative behavior is more often associated with well-defined actors (table 6b).

Furthermore, the editorials in Dagen, just as Dagens Nyheter, occasionally describe behavior attributed to Muslim actors as commendable. However, the context of these cases reveals that not all of these cases are truly commendable. For instance, Hamas is said to have come into office democratically, but is

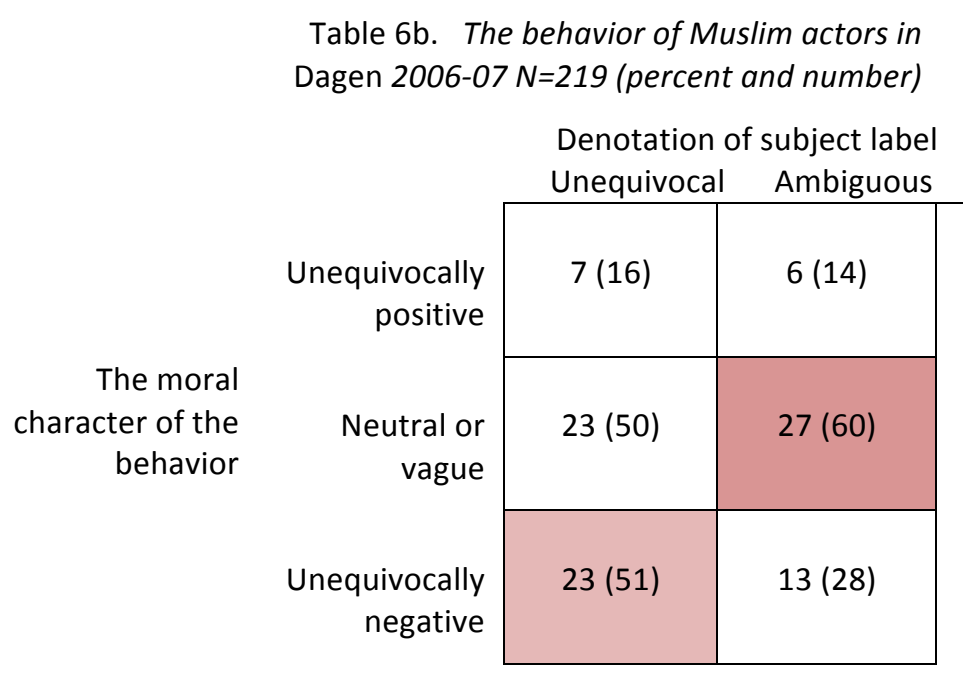

at the same time defined as a terrorist organization (Thureson, 8 June 2006). Yet, in some cases, Muslim actors are said to act truly ethically acceptably; 
Swedish Muslim representatives are said to support Christian values in the educational system (Österberg, 30 November 2006) and Arab states criticize Hamas' policies (Thureson, 18 July 2006).

The two remaining media products are drastically different. Världen idag frequently makes Muslim actors accountable for morally questionable behavior (table 6c). 65\% of Muslim behavior is morally doubtful; merely $7 \%$ is morally acceptable. $28 \%$ of the depicted behavior is morally vague or neutral.

Furthermore, morally negative behavior is repeatedly combined with ambiguous subject labels, making an undefined and large Muslim group responsible for the behavior in question. The two most common behaviors attributed to Muslims are "murder"' and "demand". During the observation period, Muslims "murder" more than 20 times. This excludes the following clauses, which have been omitted: "carried out mass murder" (Tunehag, 13 December 2006), "carry out their murderous misdeeds" (Tunehag, 4 September 2006), "engaged in mass murder" (Tunehag, 13 September 2006) or "encourage children to murder Jews" (Tunehag, 22 February 2006). Secondly, Muslims "demand", and their demands are unjust, directed towards the West and part of a zero-sum game. Everything 'they' demand is at 'our' expense.

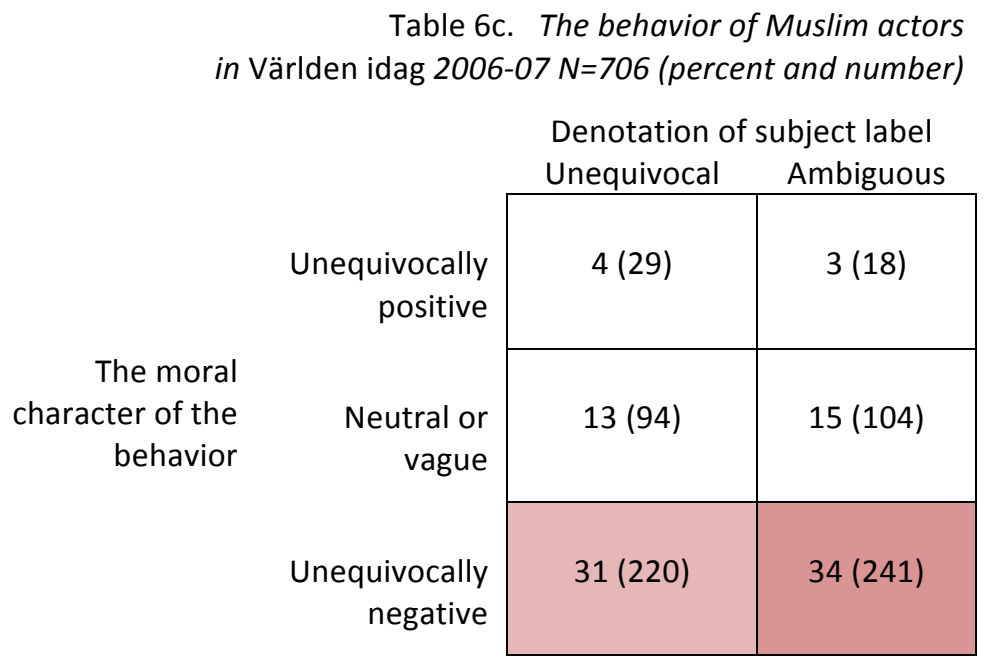

SD-Kuriren, lastly, contained 219 clauses describing Muslim behavior (table 6d). Basically $S D$-Kuriren uses the same linguistic strategy as Världen idag, perhaps somewhat harsher. $69 \%$ of alleged Muslim behavior is categorized as negative. $30 \%$ of Muslim behavior is categorized as morally neutral or ethically unclear.

In the case of $S D$-Kuriren the most common behavior ascribed to Muslims is that they "mean" (14 cases) and "participate" (nine cases). "Mean" has more or less the function as "demand" in the case of Världen idag, indicating unjust attitudes, such as Muslims "mean" that the Swedish society should adapt to them (Jomshof, 69d, 2006). 
Table $6 \mathrm{~d}$. The behavior of Muslim actors in SD-Kuriren 2006-07 N=219 (percent and number)

\begin{tabular}{|c|c|c|c|}
\hline & & Denotation & bject label \\
\hline & & Unequivocal & Ambiguous \\
\hline & $\begin{array}{l}\text { Unequivocally } \\
\text { positive }\end{array}$ & $1(2)$ & $0,5(1)$ \\
\hline $\begin{array}{r}\text { The moral } \\
\text { character of the } \\
\text { behavior }\end{array}$ & $\begin{array}{r}\text { Neutral or } \\
\text { vague }\end{array}$ & $15(32)$ & $15(33)$ \\
\hline & $\begin{array}{r}\text { Unequivocally } \\
\text { negative }\end{array}$ & $25(55)$ & $44(96)$ \\
\hline
\end{tabular}

\section{Prescriptions and Solutions}

Entman's framing analysis implies that frames are also revealed in suggested solutions to vital problems. Accordingly, different solutions, put forward in the articles, will be analyzed; more specifically, to what extent the solutions are of a problem-solving kind or based on critical theory calling for reform and emancipation. A problem-solving theory does not believe in fundamental changes to societal structures, but "takes the world as it finds it, with the prevailing

Figure 1. Categorization of prescriptions and solutions in editorials

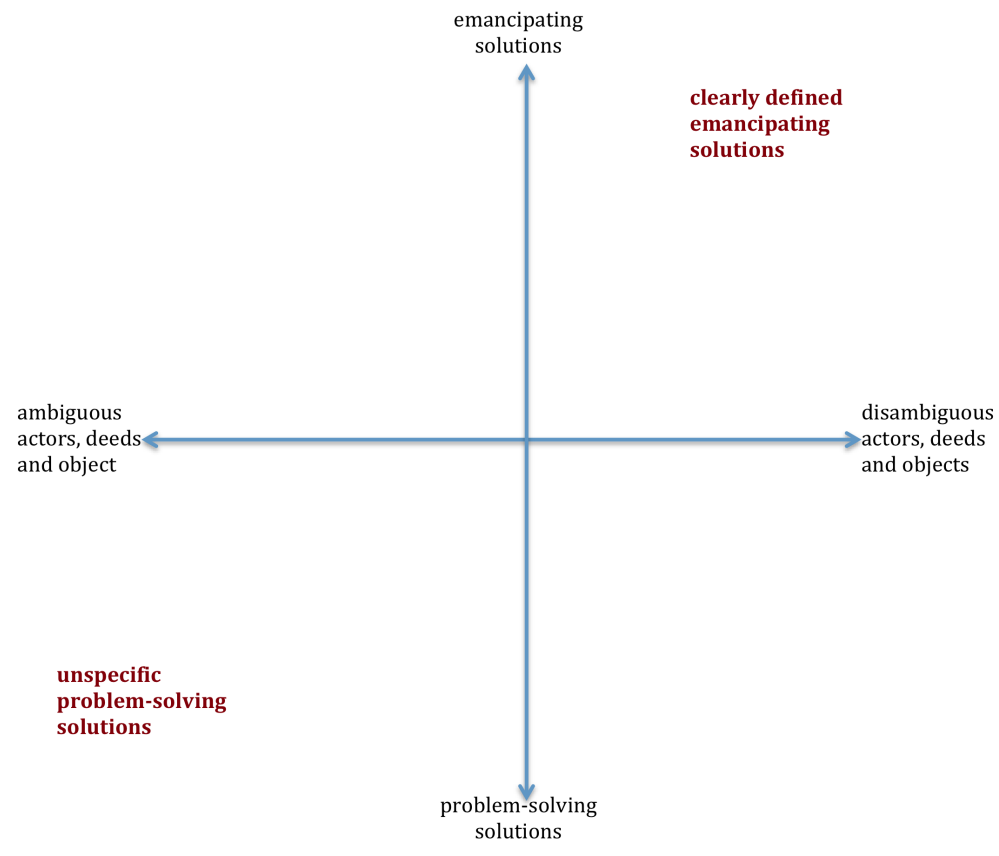

social and power relationships and the institutions into which they are organized, as the given framework for action" and only tries to "make these relationships and institutions work smoothly by dealing effectively with par- 
ticular source of trouble" (Cox, 1981: 128-29). Critical theory, on the other hand, "does not take social and power relations for granted but calls them into question" (Cox, 1981: 1929). Thus a problem-solving theory in a Huntingtonian vein, does not believe that relations between 'civilizations' can change fundamentally, merely individual issues can be addressed using deterrence or containment policies. Since critical theory believes that a new social and political order is possible given that social orders are not given but dynamic, it would suggest solutions that would change fundamental political and social structures are feasible, giving inter-civilizational relations new possibilities.

Furthermore, the precision of suggested solutions will also be evaluated; to what extent it is clear who the actor is, the character of the measure to be undertaken, and who the object of those measures is. These two discussions equal two dimensions in the current analysis, creating four possible categories (figure 1). It is reasonable to argue that unspecific problem-solving solutions are ethically more problematic that clearly defined emancipating ones.

In some editorials and political articles the solutions do not really concern Muslims. Muslims are not the principal objects of political measures, and therefore solutions in these items do not reflect political attitudes to Muslims, and cannot be classified. However, in items that concern alleged Muslim threats, Muslims are usually the object of suggested political measures and reveal attitudes to Muslims. Consequently, in the case of Dagens Nyheter, Världen idag and SD-Kuriren, editorials and political articles on Muslim threats (table 2a, c and d) will be analyzed, since they reveal whether the writers advocate problem-solving or emancipatory solutions. In the case of Dagen, another selection had to be undertaken: articles concerning "attitudes to Muslims in Sweden", "the relationship between Muslims and Christians or the western world", "the Israeli-Palestinian conflict", and "threats against freedom of expression" (table $2 \mathrm{~b}$ ) have been selected since they represent a conflictual relationship.

As table 7 indicates, the analysis reveals three important results. Firstly, all media products repeatedly avoid making explicit prescriptions. Yet, in many of these articles, the ideology of the media is clear, and can tacitly imply a solution. Even so, they have been excluded. Secondly, the rift between Dagens Nyheter and Dagen on one side, and SD-Kuriren and Världen idag on the other, reoccurs. In SD-Kuriren and Världen idag no articles with emancipating solutions occur. Dagen's solutions, on the other hand, are more often precise and emancipatory. Even in editorials concerning conflicts between the Western and the Muslim world, an attitude of reform and emancipation is present. One editorial about the policies of the Swedish Secret Police and religious extremism illustrates this emancipatory attitude; Thomas Östeberg seems to believe that fundamental attitudinal changes in the population are possible as well as required and thus proposes an "adamant work for an integration of Muslim immigrants in Sweden...” (Österberg, 26 January 2006) 
is required in order to solve terrorist threats. Likewise Dagens Nyheter claims that it is vital to make all citizens deeply rooted in democratic values, to "anchor the values of the open society in everyone living in Denmark" (Dagens Nyheter, 11 January 2006).

Still, also in Dagen, solutions of a problem-solving kind appear. In the spring 2006, three young men planned a terror attack against Livets Ord in Uppsala. In this case Thureson is clearly suggesting solutions based on a problem-solving logic (Thureson, 5 May 2006), stating that "those who want to frustrate democratic work and replace it with the tools of violence are not harmless for our society" and "to pet with violence implies undermining democracy" and furthermore "Islamophobia is not fought best with blinders on".

As said, SD-Kuriren and Världen idag clearly deviate since they never suggest emancipating solutions. Furthermore, the suggested measures are comparatively often imprecise; it is not stated who is going to act, the measures are not clearly defined and based on problem-solving theory. There is no request for readers to understand Muslims or Islam, to establish a constructive relationship with Muslims. On the contrary, the readers are encouraged to dissociate themselves from this group, and it is urgent to deter them from further aggression, to regain control over western areas from Muslim influence, and to explicitly express dissatisfaction with policies in Muslim countries. ${ }^{9}$

Table 7. Categorization of prescriptions and solutions in editorials (percent and number)

\begin{tabular}{l|c|c|c|c|} 
& $\begin{array}{c}\text { Solutions in Dagens } \\
\text { Nyheter } \\
2006-07 \\
\mathrm{~N}=23\end{array}$ & $\begin{array}{c}\text { Solutions in } \\
\text { Dagen } \\
2006-07 \\
\mathrm{~N}=30\end{array}$ & $\begin{array}{c}\text { Solutions in } \\
\text { Världen idag } \\
2006-07 \\
\mathrm{~N}=57\end{array}$ & $\begin{array}{c}\text { Solutions in } \\
\text { SD-Kuriren } \\
2006-07 \\
\mathrm{~N}=21\end{array}$ \\
\cline { 2 - 5 } & $30(7)$ & $37(11)$ & $58(33)$ & $48(10)$ \\
\hline $\begin{array}{l}\text { Articles without explicit prescriptions } \\
\text { Emancipating solutions and dis- } \\
\text { ambiguous actors, deeds and objects }\end{array}$ & $17(4)$ & $23(7)$ & $0(0)$ & $0(0)$ \\
\cline { 2 - 5 } $\begin{array}{l}\text { Emancipating solutions and } \\
\text { ambiguous actors, deeds and objects }\end{array}$ & $0(0)$ & $13(4)$ & $0(0)$ & $0(0)$ \\
\cline { 2 - 5 } $\begin{array}{l}\text { Problem-solving solutions and dis- } \\
\text { ambiguous actors, deeds and objects }\end{array}$ & $43(10)$ & $20(6)$ & $21(12)$ & $33(7)$ \\
\cline { 2 - 5 } $\begin{array}{l}\text { Problem-solving solutions and } \\
\text { ambiguous actors, deeds and objects }\end{array}$ & $9(2)$ & $7(2)$ & $21(12)$ & $19(4)$ \\
\cline { 2 - 5 } & & & & \\
\end{tabular}

By far the most common linguistic tool used in Världen idag, making the solutions imprecise, is the usage of implied prescriptions (Ejvegård, 2005: 29) such as expressive exclamations (Ejvegård, 2005: 26-27). Björk, following death threats against a Norwegian journalist, stated that "strong measures are

9 Some editorials deviate, as the writers turn to an imagined Muslim audience (Tunehag 18 September 2006) and to Swedish politicians (Björk 11 August 2006). 
required against all kinds of religion that wish to silence a democracy with violence and threats, and to take over society" (Björk, 13 January 2006). Björk clearly underlines the magnitude of the Muslim threat and implicitly calls for "strong measures" without clarifying what kind of measures that are necessary or who will carry them out. Agnarsson pursues the same method in an article where Muslims are defined as hatred incarnated that "must be fought on many levels" (Agnarsson 27 January 2006) and concludes that "our modern history teaches us that we need to be on our guard."

In the editorial $A$ Coordinated Defence is Required Stenström calls Islam a "religion of violence" (Stenström, 6 February 2006), and poses numerous rhetorical questions. Stenström asks "how can we continue to show tolerance and openness and at the same time defend ourselves against those who apparently do not?" and, "how can we defend democracy and human rights against those who despise democracy and freedom?", and, "how can we master and overcome hatred and violence when there are major groups that advocate violence?" and "how can we safeguard our culture and fundamental values?" (Stenström, 6 February 2006). I find Stenström's linguistic strategy intriguing. "We" are facing difficult dilemmas and, as Islam is described essentially as a "religion of violence", there is no ethical solution. Using these rhetorical questions, Stenström provokes the reader to find solutions of a problem-solving kind. Later Stenström draws her own conclusions: "European countries with major Muslim populations ... must ... prepare a strategy for the future. ... The civilized world must brace itself for a united resistance to this dangerous madness" (Stenström, 6 February 2006).

$S D$-Kuriren's rhetoric on solutions to Muslim issues resembles the one in Världen idag; the solutions tend to be problem-solving and in some cases imprecise. Without explaining who is supposed to act, or what kind of actions should be undertaken, Richard Jomshof makes an implicit prescription: "Just as the democratic world took the fight against Nazism in the 1930 - and 40's, we must now take the fight against the Islamists" (Jomshof, 67b, 2006). This sentence is repeated in three additional articles in 2006 and 2007 (Jomshof, 69c, 2006; Jomshof, 69d; Jomshof, 74b, 2007), the last time adding "it is now time to not merely to react, but also to act." Furthermore, SD-Kuriren also deems it hard for Muslims to live in harmony with the rest of the population. Reform is not an option. After riots in Europe in the summer 2006, Jomshof and Söder claim in a problem-solving vein, that "in order to prevent similar incidents in Sweden, we must sharply limit immigration whilst making many of the unassimilated immigrants already here to go back to their home countries or to adapt to Swedish society" (Jomshof and Söder, 67, 2006).

A third result concerns the relatively high prevalence of problem-solving solutions in Dagens Nyheter. This requires some comments though. First of all, these solutions generally concern Iran's nuclear program. Secondly, the solutions are disambiguous. The target is the Iranian regime, and the actors as well 
as the measures are well-defined. The paper suggests boycotts (Dagens Nyheter, 16 January 2006), or travel bans for Iranian officials (Dagens Nyheter, 26 February 2007). And lastly, the target of these measures, the Iranian regime, is defined as an immoral political actor, never as a Muslim one.

\section{Conclusions}

It is clear that a rift does appear in the Swedish media landscape regarding descriptions of Muslims and Islam. However, this rift does not appear between Conservative Swedish Christian media on the one side and secular ones on the other. Instead the rift divides Christian as well as secular media. Liberal Dagens Nyheter and conservative and Evangelical Dagen avoid describing Muslims and Islam as a threat and usually seek constructive solutions to different challenges. Dagen also sees Christians as well as Muslims as victims of the forces of secularization. Dagens Nyheter, moreover, describes conflicts between Muslim and Christian actors in political, not religious, terms. Furthermore, a common ground appears between the neo-nationalist journal $S D$-Kuriren and fundamentalist charismatic Världen idag. These two media repeatedly make generalizing assertions, and describe Islam and Muslims as violent, irrational, making unacceptable demands at 'our' expense, and as a danger and threat to Christians, and to the Western world, primarily, its democracy. Furthermore Western leaders are in typically populist vein allegedly submissive to Muslim demands and retreating. Världen idag, unlike $S D$-Kuriren, additionally claims that Islam is permanently inconsistent with democracy. Whether this actually portends a possible alliance between neonationalist movements and conservative Christianity could be a deriving point for future research.

\section{References}

\section{Literature}

Abrahamian, Ervand, 2003. 'The US Media, Huntington and September 11', Third World Quarterly, 24, 529-544.

Beeman, William 0., 2005. The “Great Satan" vs. the "Mad Mullahs", How the United States and Iran Demonize. Chicago: Chicago University Press.

Cox, Robert W., 1981. 'Social Forces, States and World Orders: Beyond International Relations Theory', Millennium, 10, 126-55.

van Dijk, Teun A., 1995. 'Aims of Critical Discourse Analysis', Japanese Discourse 1, 17-27.

Entman, Robert, 1993. 'Framing: Toward Clarification of a Fractured Paradigm', Journal of Communication 43, 51-58.

Ejvegård, Rolf, 2005. Argumentationsanalys, Lund: Studentlitteratur.

Galtung, Johan, 1990. 'Cultural Violence', Journal of Peace Research, 27, 3 291-305.

Hellström, Anders, 2010. Vi är de goda, Den offentliga debatten om Sverigedemokraterna och 
deras politik, Hägersten: Tankekraft förlag.

Jones, Melinda, 2002. Social Psychology of Prejudice, Upper Saddle River, NJ: Prentice Hall.

Jost, John T. and Banaji, Mahzarin R., 1994. 'The Role of Stereotyping in System-Justification and the Production of False Consciousness', British Journal of Social Psychology, 33, 127.

Landmann, Todd, 2008. Issues and Methods in Comparative Politics, An Introduction ( $3^{\text {rd }}$ ed.), London and New York: Routledge.

Massad, Joseph A., 2007. Desiring Arabs, Chicago: Chicago University Press.

Mudde, Cas, 1999. 'The Single-Issue Party Thesis: Extreme Right Parties and the Immigration Issue', West European Politics 22, 182-197.

Mudde, Cas. 2011. 'Who's Afraid of the European Radical Right?', Dissent, 7-11.

Nohrstedt, Stig Arne and Camauër, Leonor, 2006. 'Introduktion', Mediernas vi och dom, Mediernas betydelse för den strukturella diskrimineringen, Rapport av Utredningen om makt, integration och strukturell diskriminering, Leonor Camauër och Stig Arne Nohrstedt (eds.), SOU 2006:21. Stockholm: Fritzes offentliga publikationer.

Ottosen, Rune, 1995. 'Enemy Images and the Journalistic Process', Journal of Peace Research $32,97-112$.

Poole, Elizabeth, 2006. 'The Effects of September 11 and the War in Iraq on British Newspaper Coverage', Muslim and the News Media. Elizabeth Poole \& John E. Richardson (eds.). London: I.B. Tauris.

Poole, Elizabeth and Richardson, John E., 2006. 'Introduction', Muslims and the News Media. London: I.B. Tauris.

Rydgren, Jens, 2005. Från skattemissnöje till etnonationalism: Högerpopulism och parlamentarisk högerextremism i Sverige. Lund: Studentlitteratur.

Said, Edward W., 1997. Covering Islam, How the Media and the Experts Determine How We See the Rest of the World. London: Vintage.

Said, Edward W., 1978. Orientalism, London: Penguin Books.

Shaheen, Jack G., 1985. 'Media Coverage of the Middle East: Perception and Foreign Policy', American Academy of Political and Social Science, 482, 160-175.

Steiner, Kristian, 2010. "Vem är min nästa?", Bilden av islam och muslimer i den kristna nyhetstidningen Världen idag, Studier av inter-religiösa relationer 49. Uppsala: Swedish Science Press.

Steiner, Kristian, 2013. 'War and Peace Theology in German and Swedish Christian Zionism', ID: International Dialogue, A Multidisciplinary Journal of World Affairs 3, 38-76.

Sternberg, Robert J and Sternberg, Karin, 2008. The Nature of Hate. Cambridge: Cambridge University Press.

Strand Runsten, Pia, 2006. "'Hedersmord', eurocentrism och etnicitet. Mordet på Fadime, En fallstudie", Mediernas vi och dom, Mediernas betydelse för den strukturella diskrimineringen, Rapport av Utredningen om makt, integration och strukturell diskriminering, Leonor Camauër och Stig Arne Nohrstedt (ed.), SOU 2006:21. Stockholm: Fritzes offentliga publikationer.

\section{Dagens Nyheter}

Dagens Nyheter (2006) Avrätta inte Saddam Hussein (editorial) 6 November.

Dagens Nyheter (2006) Demokratin är fortsatt utmanad (editorial) 7 July.

Dagens Nyheter (2006) Demokratin hann försvara sig (editorial) 11 August.

Dagens Nyheter (2006) En svensk tragedi valåret 2006 (editorial) 19 April.

Dagens Nyheter (2006) Inget öppet samhälle utan hädelse (editorial) 11 January.

Dagens Nyheter (2006) Iranska kärnvapen vore en mardröm (editorial) 16 January.

Dagens Nyheter (2007) Ond mix i Pakistan (editorial) 14 November.

Dagens Nyheter (2007) Slöjan hotar ingen (editorial) 27 September. 
Dagens Nyheter (2006) Stoppa trängseln vid stubintråden (editorial) 7 February.

Dagens Nyheter (2006) Än är Turkiet inte förlorat (editorial) 13 May.

\section{Dagen}

Cyrillus, (Olsson), Erika (2006) FP sviker kristna skolor (editorial). Dagen 22 August.

Cyrillus, (Olsson), Erika (2006) Påven öppnar för dialog (editorial). Dagen 28 November.

Cyrillus, (Olsson), Erika (2006) Stoppa palestinskt blodbad (editorial). Dagen 14 June.

Cyrillus, (Olsson), Erika (2006) Vansklig fredslösning (editorial). Dagen 15 November.

Grahn, Daniel (2006) Dialog - inte demonisering (editorial). Dagen 10 February.

Sandlund, Elisabeth, (2007) När doktorn blir terrorist (editorial). Dagen 5 July.

Thureson, Birger (2006) En misslyckad strategi (editorial). Dagen 1 August.

Thureson, Birger (2006) Israel efter Ariel Sharon (editorial). Dagen 10 January.

Thureson, Birger (2006) Krig ett dåligt vapen (editorial). Dagen 8 June.

Thureson, Birger (2006) Svårartad kulturkrock (editorial). Dagen 1 February.

Thureson, Birger (2006) Terrorism på svenska (editorial). Dagen 5 May.

Österberg, Thomas (2007) Ensidighet hindrar fred (editorial). Dagen 5 June.

Österberg, Thomas (2006) Farligt nej till julspel (editorial). Dagen 30 November.

Österberg, Thomas (2007) Hopp och tvivel om fred (editorial). Dagen 21 November.

Österberg, Thomas (2006) Hot mot 'blomstertiden' (editorial). Dagen 13 June.

Österberg, Thomas (2006) Irak allt svårare för Bush (editorial). Dagen 26 September.

Österberg, Thomas (2007) Lång väg kvar till fred (editorial). Dagen 4 April.

Österberg, Thomas (2006) Registrera inte tro, Säpo (editorial). Dagen 26 January.

Österberg, Thomas (2006) Sårbarheten finns kvar (editorial). Dagen 11 August.

Österberg, Thomas (2006) Vapenvila utan segrare (editorial). Dagen 17 August.

\section{Världen idag}

Agnarsson, Ruben (2006) Hatet mitt ibland oss (editorial). Världen idag 27 January. Agnarsson, Ruben (2006) Övningen i Boden (editorial). Världen idag 18 January.

Björk, Hans-Göran (2006) Dödshoten islams rätta ansikte? (editorial). Världen idag 13 January. Björk, Hans-Göran (2006) Falsk rapportering är förödande (editorial). Världen idag 9 August. Björk, Hans-Göran (2006) Hamas fick legitimitet i Sverige (editorial). Världen idag 8 May. Björk, Hans-Göran (2006) Sluta flirta med terrorister (editorial). Världen idag 11 August. Björk, Hans-Göran (2006) Ursäkten blev kapitulation (editorial). Världen idag 3 February. Stenström, Carin (2006) Nu krävs samordnat försvar (editorial). Världen idag 6 Februay. Tunehag, Mats (2006) Demokratin går framåt och bakåt (editorial). Världen idag 13 December. Tunehag, Mats (2006) Folkpartister talar klarspråk (editorial). Världen idag 6 September. Tunehag, Mats (2006) Iran, kärnvapen och den 12:e imamen (editorial). Världen idag 22 February.

Tunehag, Mats (2006) Islam hotar Danmark - Persson tiger (editorial). Världen idag 2 January. Tunehag, Mats (2006) Islams benägenhet till våld (editorial). Världen idag 25 September. Tunehag, Mats (2006) Islams fyrkantiga cirklar (editorial). Världen idag 31 March. Tunehag, Mats (2006) Islamsk intolerans når nya höjder (editorial). Världen idag 1 February. Tunehag, Mats (2006) Islamska republiken Sverige (editorial). Världen idag 8 March. Tunehag, Mats (2006) Jämtin och muren i Saudiarabien (editorial). Världen idag 4 September. Tunehag, Mats (2006) Kan islam moderniseras? (editorial). Världen idag 27 February. Tunehag, Mats (2007) Kebab utan sharia, tack (editorial). Världen idag 31 January. 
Tunehag, Mats (2006) Kristna lever farligt (editorial). Världen idag 12 July.

Tunehag, Mats (2006) Lika goda kålsupare (editorial). Världen idag 8 November.

Tunehag, Mats (2006) Mecka-kyrka och Malmö-moské (editorial). Världen idag 14 June.

Tunehag, Mats (2006) Påven och islam (editorial). Världen idag 18 September.

Tunehag, Mats (2006) Sekularister banar väg för jihadister (editorial). Världen idag 7 Juni.

Tunehag, Mats (2006) Ska alla tvingas följa islam? (editorial). Världen idag 13 February.

Tunehag, Mats (2006) Skamfläckar och hot (editorial). Världen idag 10 March.

Tunehag, Mats (2006) Sopspioner mot terrorister? (editorial). Världen idag 14 Augusti.

Tunehag, Mats (2006) Val inte lika med demokrati (editorial). Världen idag 30 January.

\section{SD-Kuriren}

Jomshof, Richard (2007). Den "nya våldtäktsvågen". SD-Kuriren 74a.

Jomshof, Richard, (2007). Göteborgsmoské byggs med pengar från Saudiarabien. SD-Kuriren 72a.

Jomshof, Richard, (2006). Islamiseringen av Sverige. SD-Kuriren 69a.

Jomshof, Richard, (2007). Islamiseringen av Sverige. SD-Kuriren 74b.

Jomshof, Richard, (2006). »Muhammed har avbildats tusentals gånger genom historien». $S D$ Kuriren 67a.

Jomshof, Richard, (2006). "Muhammed har avbildats tusentals gånger genom historien". SDKuriren 69b.

Jomshof, Richard, (2007). Muhammedkonflikten fortsätter. SD-Kuriren 74c.

Jomshof, Richard, (2006). Muslimska protester mot Danmark. SD-Kuriren 69c.

Jomshof, Richard, (2007). Om yrkesapartheid och självförakt. SD-Kuriren 71.

Jomshof, Richard, (2006). Protester mot Danmark. SD-Kuriren 67b.

Jomshof, Richard, (2007). Rondellhunden Muhammed stopped. SD-Kuriren 73.

Jomshof, Richard, (2006). SD-Kuriren granskar och avslöjar islam i Sverige. SD-Kuriren 69d.

Jomshof, Richard, (2006). Sharia oförenligt med demokrati. SD-Kuriren, 68.

Jomshof, Richard, (2007). Upplopp i Nederländerna. SD-Kuriren 72b.

Jomshof, Richard and Söder, Björn (2006). Kravaller skakade Europa. SD-Kuriren 67.

Karlsson, Mattias (2007). Rätt av Åkesson att ta debatten. SD-Kuriren 72a.

Karlsson, Mattias, (2007). Ungdomsrånen-ett krig mot svenskarna. SD-Kuriren 74.

Karlsson, Mattias, (2006). Universitetsstudie: Ungdomsrånen är ett krig mot svenskarna. $S D$ Kuriren 68.

Karlsson, Mattias, (2007). Upprorisk tonåring eller mammas flicka?. SD-Kuriren 72b.

Söder, Björn (2007). Fegisarna diskuterar. SD-Kuriren 73.

Söder, Björn, (2006). Söder: Vi måste våga ifrågasätta islam. SD-Kuriren 67.

Söder, Björn, (2006). "Vi måste våga ifrågasätta islam". SD-Kuriren 69.

Wiklander, Tony (2006). Ecce homo Muhammed. SD-Kuriren, nr 67.

Åkesson, Jimmy (2007). Att ta den berömda debatten... SD-Kuriren 72.

Dr. Kristian Steiner is a Senior Lecturer and responsible for Peace and Conflict Studies at Malmö University, Sweden. Steiner has published on the construction of Muslims in Swedish Christian and secular press. Currently he is working on the understanding of peace in German and Swedish Christian Zionism. 